\title{
The split skin graft donor site: Can pretreatment with vitamin A cream help?
}

\author{
PJ Skoll FRCS, M Soldin FCSSA, M Grob MD, B Seymour MTech, J Davies FCPathSA, \\ H Rode FRCS, DA Hudson FRCS
}

PJ Skoll, M Soldin, M Grob, et al. The split skin graft donor site: Can pretreatment with Vitamin A cream help? Can J Plast Surg 2002;10(2):78-80.

BACKGROUND: A skin graft donor site that heals rapidly with less cosmetic sequelae is of particular benefit to children with burns. Vitamin A cream has been shown to speed up healing after controlled 'burns' (dermabrasion and $\mathrm{CO}_{2}$ laser) if it is applied six weeks before treatment.

OBJECTIVE: To assess whether pretreatment with vitamin A cream increases the rate of healing of split skin graft donor sites in children with burns.

METHODS: Prospective study of children with hot water burns of $8 \%$ to $30 \%$ that required split thickness skin grafting. Vitamin A cream was applied bidaily to one thigh and/or buttock of each child for five to seven days before skin grafting. At surgery, equal thickness grafts were harvested from both thighs and/or buttocks. Biopsies were taken from each thigh and/or buttock and were sent for histological analysis. The rate of donor site healing was monitored clinically and with serial photographs.

RESULTS: No difference in the rate of healing was noted between the treated and untreated sides by either histological or clinical criteria.

CONCLUSIONS: Vitamin A cream applied bidaily for a period of five to seven days did not affect the healing rate of the split skin graft donor sites in children with burns.

Key Words: Burns; Skin graft donor site; Vitamin A cream
La zone de prélèvement d'une greffe dermo-épidermique : Un prétraitement à l'aide de crème à la vitamine $A$ peut-il être utile ?

HISTORIQUE : La zone de prélèvement d'une greffe épidermique qui guérit rapidement et s'accompagne de peu de séquelles esthétiques est particulièrement bénéfique pour les enfants brûlés. Il est démontré que la crème à la vitamine A accélère la cicatrisation après des "brûlures" contrôlées (dermabrasion et laser à gaz carbonique) lorsqu'elle est appliquée six semaines avant le traitement.

OBJECTIF : Évaluer si un prétraitement à l'aide de crème à la vitamine A accroît le rythme de cicatrisation de la zone de prélèvement d'une greffe dermo-épidermique chez des enfants présentant une brûlure.

MÉTHODOLOGIE : Étude prospective d'enfants présentant des brûlures de $8 \%$ à $30 \%$ de leur surface corporelle, causées par un liquide bouillant, et qui ont dû subir une greffe dermo-épidermique. De la crème à la vitamine $\mathrm{A}$ a été appliquée deux fois par jour sur une cuisse ou une fesse de chaque enfant pendant cinq à sept jours avant la greffe. Au moment de l'opération, des greffes d'égale épaisseur ont été prélevées sur les deux cuisses ou fesses. Des biopsies ont également été prélevées sur chaque cuisse et fesse et ont fait l'objet d'une analyse histologique. Le rythme de cicatrisation de la zone de prélèvement a été surveillé en clinique et au moyen de photographies sérielles.

RÉSULTATS : Aucune différence n'a été remarquée dans le rythme de cicatrisation du côté traité ou non traité, que ce soit selon les critères histologiques ou selon les critères cliniques.

CONCLUSION : Une crème à la vitamine $\mathrm{A}$ appliquée deux fois par jour pendant cinq à sept jours ne modifie pas le rythme de cicatrisation des zones de prélèvement d'une greffe dermo-épidermique chez les enfants brûlés.

Department of Plastic Surgery, Paediatric Surgery and Pathology, University of Cape Town, Cape Town, South Africa

Correspondence: Dr PJ Skoll, University of Cape Town, Groote Schuur Hospital, OMB, Department of Plastic E⿱ Reconstructive Surgery, H53/69, Observatory 7925, Cape Town, South Africa. Telephone +27-21-404-3426, fax +27-21-448-6461, e-mail plastics@uctgsh1.uct.ac.za 
Tn the past decade, greater attention has been paid to the 1 cosmetic aspects of both the acute treatment and the reconstruction of burns. Skin graft donor sites are now considered carefully in an attempt to best conceal them. For example, the buttock is now used more commonly as a donor site for a split skin graft.

A split skin graft donor site that heals more rapidly is of great benefit to the patient. It allows earlier, repeat harvesting of split skin grafts, which may be necessary in large burns, and by healing more quickly, there is less pain to endure. Furthermore, rapid healing may also lead to a better cosmetic outcome of the donor site.

Vitamin A cream is used widely in plastic surgery because it is known to promote epithelialization (1-7). This study was undertaken to assess whether pretreatment with vitamin $A$ increases the rate of healing of split skin graft donor sites in children with burns.

\section{METHODS}

A study was undertaken to investigate the effect of pretreatment with topical vitamin A (Environ, South Africa) on the rate of wound healing of split skin donor sites in children under the age of 12 years (the upper age limit for admission to Red Cross Childrens' Hospital, Cape Town, South Africa). All indeterminate hot water burns ( $8 \%$ to $30 \%$ total body surface area in the study) in children were initially managed expectantly with dressings. Those with a deep element to the burn were treated subsequently with a split skin graft, usually five to seven days after admission.

In this study, vitamin A cream $(0.01 \%)$ was applied bidaily to one thigh and/or buttock, for five to seven days. At surgery, equal thickness split skin grafts were harvested from both thighs and/or buttocks and a polyurethane dressing was applied (one thigh acted as an untreated control). A biopsy was taken from each thigh and sent for histological analysis. The procedure was performed on 12 children.

\section{Clinical assessment}

The donor sites were monitored clinically and photographed on days 3, 5, 7 and 10 to assess the rate of healing. The photographs were assessed by a blinded observer. A grid pattern was applied to the wounds and the healing was assessed arbitrarily as $25 \%, 50 \%$ or greater than $75 \%$ healed.

\section{Histological assessment}

The following histological criteria were assessed using a quantitative scoring system.

- The degree of basal epithelial hyperplasia (mitotic activity, presence of nucleoli)

- The amount of epithelial spongiosus

- The amount of inflammation within the papillary and reticular dermis
- The amount of edema within the papillary and reticular dermis

Measurements and counts of these histological criteria were performed using Optimas Version 6.2 software (Microsoft Corporation, USA), which allowed for semiautomated measurements.

The following were counted using the above system.

- The number of mitotic figures in the stratum basalis of the epidermis

- The number of capillaries in the papillary dermis

- The number of polymorphonuclear leukocytes in the papillary dermis (acute inflammation)

- The number of lymphocytes in the papillary dermis (chronic inflammation)

Five fields at $400 \times$ original magnification, measuring approximately $28,300 \mu^{2}$, were captured to incorporate the dermis-epidermal junction and the entire length of the biopsy in most cases.

The study was approved by the Ethics Committee of the University of Cape Town.

\section{RESULTS}

Although serial clinical examination and photographs of the healing donor sites suggested a marginally faster healing time on the vitamin A-treated side, this was not borne out by histological examination that compared treated and untreated biopsy sites, and where no clear difference in healing rates could be detected.

\section{DISCUSSION}

The role of vitamin A or its analogues is well established in cosmetic plastic surgery (1-5). When used for six weeks before laser treatment, acid peel (both 'controlled burns') or dermabrasion, the treated area shows accelerated reepithelialization and, thus, an increased rate of healing. This has also been shown in experimental work, where 0.05\% vitamin A cream applied daily for 10 days, before partial thickness wounds inflict upon, had a beneficial effect on wound epithelialization (6). It was hoped that, in burn patients who required split skin grafts, pretreatment with vitamin A cream would increase the rate of healing and, hence, would allow more frequent skin harvesting from the same donor site, should this be required. It was similarly anticipated that the pigmentary problems that occur at the donor site may also be minimized because vitamin $A$ cream has been shown to be effective in this regard (5-7).

The authors believe that, had the vitamin A cream been applied for a longer period, a difference would probably have been demonstrated. At this stage, however, the optimal period of pretreatment that is required is not known. This method of pretreatment of the donor site would not be applicable to burn patients who undergo immediate tangential excision and skin grafting. 
The authors support the notion that the skin graft donor site is an important cosmetic factor in the management of all burn patients. Diminishing morbidity and increasing the rate of donor site healing has obvious implications for all who are involved in the management of burn patients.

\section{REFERENCES}

1. Graf RM, Bernandes A, Noronha L. Full face laser resurfacing and rhytidectomy. Aesthet Plast Surg 1999;23:101-6.

2. Apfelberg DB. Ultrapulse carbon dioxide laser with CPG scanner for full face resurfacing for rhytids, photoaging and acne scars. Plast Reconstr Surg 1997;99:1817-25.
3. Vagotis FL, Brundage SR. Histologic study of dermabrasion and chemical peel in an animal model after pre-treatment with Retin-A. Aesthet Plast Surg 1995;19:243-6.

4. McDonald WS, Beasley D, Jones C. Retinoic acid and $\mathrm{CO}_{2}$ laser resurfacing. Plast Reconstr Surg 1999;104:2229-35.

5. Alster TS. Discussion: Retinoic acid and $\mathrm{CO}_{2}$ laser resurfacing. Plast Reconstr Surg 1999;104:2230-8.

6. Hung VC, Lee JY, Zitelli JA, Hebda PA. Tropical tretinoin and epithelial wound healing. Arch Dematol 1989;125:65-9.

7. Bulengo-Ransby SM, Griffiths CE, Kimbrough-Green CK, et al. Topical tretinoin (retinoic acid) therapy for hyperpigmented lesions caused by inflammation of the skin in black patients. N Engl J Med 1993;328:1438-43. 